\title{
American Poetry: The Divided Tradition
}

\author{
Paul Dolan \\ State University of New York at Stony Brook
}

\begin{abstract}
What is American poetry? This paper is a history of the various answers poets have given to that question. They include Whitman's creation of a new form for poetry, one to replace those inherited from England. This new poetry was as radical politically as it was poetically -it was created to include those that other poetic forms had left out. Frost, on the other hand, adapted British verse forms to an American scene and American verse. The contradictory nature of America's response to Europe has shaped the divided tradition of American poetry.
\end{abstract}

William Carlos Williams once said, «It is very easy to talk about American poetry because there isn't any such thing.» I have set myself, then, an easy task: to write about American poetry and how it came into being.

Perhaps I should say «beings,» because what Williams meant, in his anger, was that there wasn't enough of what he thought of as American poetry to make up what could be called American poetry. I want to describe the different kinds of poetry which can legitimately claim to be American; to describe, in short, a divided tradition.

Where and when then does American poetry begin? Anne Bradstreet lived in Massachusetts and wrote fine poetry. But that was the Massachusetts Bay Colony in which she lived and she never thought of herself as anything but British. If, however, good poetry written within the current geographical boundaries of the United States is the determining criterion, then American poetry begins with Anne Bradstreet. I am, however, uneasy with that as a criterion, especially when I note a Cambridge University Bulletin which describes a course in contemporary British poetry and includes Robert Lowell, Sylvia Plath and Seamus Heaney!

On the other hand, three hundred years after her book appeared, John Berryman wrote his brilliant poem «Homage to Mistress Bradstreet,» a tribute to the first of many who struggled to write poetry in the harsh and inhospitable landscape of America.

Now skip more than a century and a half and pick up the story with America already an independent country. The year is 1817 . The Constitution has been ratified, Louisiana has been purchased and the War of 1812 -the second war for American independence- has been won. A young man, William Cullen Bryant, living in the state of Massachusetts, writes a very good poem of some eighty lines entitled "Thanatopsis» 
-a meditation on death. He hides it in his desk because he does not think it good enough to submit for publication, but he tells a few people exactly where it is hidden. As, of course, he had hoped, his father found it and sent it off to The North American Review, the leading intellectual magazine in America.

The editor sent it back with an indignant letter. How dare Mr. Bryant attempt such a brazen fraud? How dare he say his son was the author of this poem? Anyone, the editor said, could see that this poem was far too good to have been written by an American and had to have been written by someone British!

Even William Carlos Williams would admit we've come a long way from there.

But the editor's attitude is significant. America was fully independent and on the way to being powerful -the Monroe Doctrine was only six years away- but America had -and in some places still has- a colossal inferiority complex about things British. (Forgive the oxymoron.) A poem so good it had to have been writ by a Brit! But the question or problem of the relation of American poetry to British will never go away; it is a major element in the division of American poetry into different things. I will return to this point in my discussion of the poetic practice of Robert Frost and T. S. Eliot.

Two theoreticians who also wrote poetry come next. Let's take Poe first. Appropriately he gave to American poetry a haunted legacy. On the one hand, he freed that poetry from the need of being serious, noble and uplifting. Poetry could be, and much of it would be, morbid, urban and technical rather than didactic. On the other hand, this dark oracle said that the poem must be short. How can so large, so grand a country limit itself to a short poem? The twentieth century landscape is littered with the colossal wrecks of the poems that sought to prove Poe wrong.

I don't know if Ralph Waldo Emerson knew of Bryant's experience with the editor of The North American Review, but he knew very well that editor's bias and he was determined to change it. After all, Noah Webster had published An American Dictionary of the English Language in 1828. We had claimed our portion of the language. When, asked Emerson, would we claim our portion of the poetry?

So Emerson, in that remarkable series of early essays, demanded that there be an American poetry, a poetry of the "new lands, new men, new thoughts" that were America. Then, sixty-one years and fifty-eight days after the more famous one, he delivered America's declaration of intellectual independence. In his Oration delivered before the Phi Beta Kappa Society, printed as The American Scholar, Emerson proclaimed, «Our day of dependence, our long apprenticeship to the learning of other lands, draws to a close.» And, in a phrase that can stand for virtually all subsequent American poetry, he urged the poet to say to the world, "This is my music. This is myself!»

But it was not only in his public lectures that he called for a new American poetry. In his Journal, he wrote, «Give me initiative, spermatic, prophesying, man-making words.» (In that same Journal, he noted, «People do not deserve to have good writing, they are so pleased with the bad.»)

It is, however, as you have probably already guessed, Emerson's essay The Poet, published in 1844, on which I wish to concentrate. This famous essay needs no special gloss, but I would mention something in it that I have lately noticed. In this stirring call for a poet to match the mountains, there is a poignant undertone. Emerson wanted to 
be that poet, but this sane, sensible and generous man knew that he did not have the qualities he said were necessary: «abandonment,» «wildness,» «insanity.»

So he calls for an American Milton whose poetry will justify the ways of America to the world. Like that earlier Puritan, Emerson believed that, «The sublime vision comes only to the pure soul in a clean and chaste body.» It is to his credit that he was able to recognize his new poet even though his body was not completely chaste, nor even fastidiously clean.

But I'm getting ahead of myself. In this essay, Emerson makes the statement which, more than any other, called his American poetry into being. It is one of those American phrases, like, «All men are created equal,» which is uttered with full conviction and sincerity and yet has more revolutionary implications than its maker ever imagined. In defining the kind of poetry he wanted for America, Emerson wrote, «For it is not metres, but a metre-making argument, that makes a poem -a thought so passionate and alive, that, like the spirit of a plant or an animal, it has an architecture of its own, and adorns nature with a new thing.»

The emphasis in Emerson's mind was on the "argument.» He wanted poetry that was serious and transforming. He had no patience with Poe's technical virtuosity -that produced only «jingles.» But he had said the words and all that awaited was a change in emphasis. Emerson, knowing he was not the poet, could only call for him: «America is a poem in our eyes; its ample geography dazzles the imagination and it will not wait long for metres.»

America actually waited eleven years, until, in 1855, Walt Whitman slouched onto the scene and, with Leaves of Grass, changed the course of poetry in America and the world.

Whitman was thirty-six years old when Leaves of Grass was published and he said of himself, «I was simmering, simmering, simmering and it was Emerson who brought me to a boil.» What brought him to a boil was not the call for a poet to catalogue America, it was the declaration that poems were not made by metres, that a poem did not have to fit a form, that a poem was its own form and had «an architecture of its own.» Call it "poetry» or call it "free verse,» Whitman changed Emerson's emphasis and saved the life of poetry -at least for the English-speaking world. Whitman's achievement -the creation of free verse- is comparable to that of Cezanne in painting or Schönberg in music or Gropius in architecture. The new work does not have to look like or sound like that which has been done before. A new art is a wholly new way of seeing, hearing, doing, being.

I want to pause here to do some slightly tedious reviewing -or, if I spoke British, to do a revision. When Chaucer wrote:

Whan that April with his showres soote

The droughte of March hath perced to the roote,

English poetry was committed to the iambic line of five beats, ten syllables. I don't know why English poetry is based on that five beat line. The answer lies partly in biology, partly in psychology, partly in linguistics and will never be completely known anyway. But from Chaucer to Shakespeare to Milton to Dryden to Pope to Wordsworth to Tennyson, the iambic line was where you started and where you finished -no matter what kind of fascinating riffs you blew in between. With the regular beat -those metres that Emerson scorned- came regular forms: sonnets, ballads, odes, couplets, 
blank verse, all the paraphernalia of poetry that for more than four hundred years had been thought as essential to poetry as skis to skiing, or even water to swimming.

But as Whitman said about the great poems of the past in his Backward Glance O'er Travel'd Roads, «Is there one that is consistent with these United States? Is there one whose underlying basis is not a denial and insult to democracy?»

There it is in a nutshell. A new political order requires a new poetical order. Of course, American poets have what Whitman called, «the mighty inheritance of the English language,» and its poems. But, he adds boldly, all of them are only a preparation for what the American poets will proceed to do. His claims are still stunning and/or inspiring, and I wish I had space for more. But let my crude summary stand. In the year of our Lord 1855, the American poet will not be independent of Her Sovereign Majesty Victoria Regina unless he stops using the forms of poetry created by and used by the loyal subjects of that majesty.

American poetry begins on 4 July 1855, seventy-nine years after America began, when someone read, «I celebrate myself and sing myself.» A new poet had thrown his gauntlet - or better, his sweat-stained workman's glove- at the feet of Virgil. This new man, this American was going to be the subject of his epic.

There is much more to be said about Whitman, for as he said of himself, «I am large, I contain multitudes.» But I want to concentrate on the ways in which he changed the nature of poetry in English, and I hope a few examples will suffice.

In the sixteenth section of Song of Myself, Whitman writes, in his free, long and argument-determined line, of the following Americans:

The opium-eater reclines with rigid head and just-open'd lips,

The prostitute draggles her shawl, her bonnet bobs on her tipsy and pimpled neck,

The crowd laugh at her blackguard oaths, the men jeer and wink to each other,

(Miserable! I do not laugh at your oaths nor jeer you)

The President holding a cabinet council is surrounded by the great secretaries,

On the piazza walk three matrons stately and friendly with twined arms.

Whitman knew that poetry had to be «free» in both form and content if it was to live and prosper. So the «metre» of these lines -if one can use that word at all- is revolutionary, but so is the «argument»: the juxtaposition in this transformed Homeric catalogue of the opium-eater, the prostitute, the president and his cabinet and those three respectable matrons; each entitled to an equal space in the poem. This is democratic poetry with a vengeance!

Whitman made his lines long because he wanted them to be inclusive; ample, welcoming, non-exclusive lines. And he had the political, the moral and the personal courage of his poetical convictions. America was to be open to all, and his poems, with their long, embracing lines, would serve as a model.

One more example, before I leave Whitman, of the nature of his «new» poetry. I'll start, however, with his only "old» one. When President Lincoln was assassinated in April 1865, Whitman was devastated. He had loved the man and, naturally, sought to express his grief in verse. But the poem he wrote was unlike anything else he had written. He wanted, I think, for his expression of grief, the wide audience his revolutionary poetry had, ironically, denied him. The poem is the very regular, very formal and very traditional «O Captain, My Captain.» I'll quote some of it: 
O Captain! my Captain! Our fearful trip is done,

The ship has weather'ed every rack, the prize we sought is won,

The port is near, the bells I hear, the people all exulting,

While follow eyes the steady keel, the vessel grim and daring;

But O heart! heart! heart!

$O$ the bleeding drops of red,

Where on the deck my Captain lies,

Fallen cold and dead.

My Captain does not answer, his lips are pale and still,

My father does not feel my arm, he has no pulse nor will,

The ship is anchor'd safe and sound, its voyage closed and done,

From fearful trip the victor ship comes in with object won;

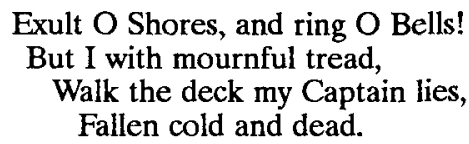

Two points need to be made about this poem. The first is that, in personifying the president as the captain of the ship of state, Whitman is using a handed-down, wellknown and unoriginal symbol. He uses it well, but this is not a poem that "has an architecture of its own and adorns nature with a new thing.» And perhaps more important is the realization by the reader that you cannot write about opium-eaters and prostitutes in this metre. The metre will mock the content or the reader "or both. Suddenly Whitman's real achievement is clearer.

And he could not let so uncharacteristic a poem be his only tribute to the man he loved, and shortly after it, he wrote another:

When lilacs last in the dooryard bloom'd,

And the great star early droop'd in the western sky in the night,

I mourn'd, and yet shall mourn with ever-returning spring.

$* * * * *$

For the sweetest, wisest soul of all my days and lands -and this for his dear sake,

Lilac and star and bird twined with the chant of my soul,

There in the fragrant pines and the cedars dusk and dim.

This was his music. This was his self.

Logically now I should go to those who began where Whitman left off, to William Carlos Williams and Allen Ginsberg. Or even to those who declined, usually impolitely, to accept Whitman's invitation to join him. That would be too straight. A true story and/or a good story involves slants and detours and circuits. So I want to turn now to a contemporary of Whitman, his opposite in every way except in the only one that matters: total devotion to the creation of a new kind of poetry. I refer, of course, to Emily Dickinson, who declined to read Whitman because she had heard he was «disreputable.» 
This strange, shy spinster buried herself alive in her family home in Amherst, Massachusetts, and then sent her letter to the world -a letter we are only beginning to learn to read. It's difficult to talk of the «influence» of Emily Dickinson. She published only seven poems in her lifetime and her executors published very selective and clumsily edited versions of her poems. But her special «tone,» her special music came through the awkward presentation. One of the small number of readers of the first posthumously published selections of her poems was the young Robert Frost. He learned well, from her example, both devotion to one's art and severity of style. As Whitman's lines are long and loose, hers are short and sinewy. As she said of herself, she is «Empress of Calvary,» and her style is true to that. For, «Agony is frugal.»

If I link Emily Dickinson, the bashful virgin of Amherst, with Ernest Hemingway, the macho basher of bulls, I risk outraged titters on one side and ineffectual punches on the other. But what the two had in common was an unshakable conviction that literary art should be lean. "Prose is architecture,» Hemingway said, "not interior decoration.» And the poet of interior desolation would have agreed. No padding. No persiflage. No rhetoric. No bombast. The thing to do with the sentence and the poem is to strip it. No Miltonic organ tones. Nothing like what Tennyson was writing at the same time she was:

Gazing at the lydian laughter of the Garda lake below,

Sweet Catullus's all-but-island, olive, silvery Sirmio.

That is beautiful. That is mellifluous. That is surely poetry. But is it English?

No. For Emily Dickinson, poetry worked in other ways its wonders to perform.

Tell all the Truth but tell it slant-

Success in Circuit lies

Too bright for our infirm Delight

The Truth's superb surprise

As Lightning to the Children eased

With explanations kind

The Truth must dazzle gradually

Or every man be blind-.

Tight. Tough. Ironic. Laconic. She saw, as she said, «New Englandly.» How else present the tragedy of a life of quiet desperation in eight lines:

The Heart asks Pleasure -first-

And then -Excuse from Pain-

And then -those little Anodynes-

That deaden suffering-

And then - to go to sleep-

And then - if it should be

The will of its Inquisitor

The privilege to die-

A standard joke about American fiction is that it is divided between the "putterinners,» like Faulkner, and the «taker-outters,» like Hemingway. So is American poetry 
-between the «putter-inner» Whitman and the «taker-outter» Dickinson. Long lines versus short lines. Poetry of inclusion and poetry of allusion. Poetry of abundance and poetry of measure. Poetry of affirmation and poetry of ironic qualification. The barbaric yawp of Whitman and the chilling whisper of Dickinson. Poetry raw and poetry cooked.

This is one of the most fundamental of the divisions of American poetry, but I want also to identify some of the other participants in the shaping of this thing called American poetry, which Williams said didn't exist anyway. I even want to consider Williams's contribution to this non-existent thing.

After the 1881 edition of Leaves of Grass, poetry in America went into a deep decline. Dickinson hadn't been published and Whitman's creative impulses were virtually exhausted. But between 1874 and 1888, there was born a generation of American poets that constitute a clustering of genius fully the equal of that of the British Romantic poets and the Elizabethan dramatists. Frost, 1874; Williams, 1883; Pound, 1885; and Eliot, 1888. They knew each other and often didn't like each other, but what mattered was the poetry they made.

To chart the course of that poetry, it is necessary to leave America, because in the closing days of «the Gilded Age," there was place for neither poets nor poetry. We have come to London. It's cold, damp, sooty, foggy, smoky, and it's 1912. Two American poets are there and they meet in a bookstore -Robert Frost and Ezra Pound. Frost will return to America in 1914, but by then Pound will have made friends with another American, Tom Eliot, recently arrived from St. Louis, Missouri, by way of Harvard. The three made a revolution in the poetry of England and America and even, it is safe to say, of the world. They had come to England for different reasons, but each had an idea that he could do something with/to/for poetry in English.

Frost, thirty-eight years old, with wife and family, had come to London to find a publisher. There was none for his kind of poetry in America. With the aid of the younger, brasher Pound, he got a publisher, and his career was launched. But then, like the Puritans three hundred years before him, he sailed from England to find a haven for his poetical beliefs in New England.

What he wanted to do was to take the mighty inheritance of the English language and graft onto it American branches. He did not want to deny British forms and models, he wanted to Americanize them, to make the iambic line «sound American.» An analogy: the American judicial system begins with the British, but it evolves a Supreme Court. That anomalous institution is completely non-democratic in structure, and yet it had done as much as anyone or anything to preserve democracy in America.

Starting from the base of British poetry, Frost wanted to make his poetry an American institution (and he succeeded!). So Frost puts himself in direct opposition to Whitman. The task of the American poet is not to create wholly new forms; it is to use the old ones in new ways. The basic task is to adapt the iambic line to American speech. That is why so many of Frost's poems are monologues and dialogues: he wants to capture the speaking voice, the voice that will renew the form in which it is cast.

Frost was witty at Whitman's expense. «Writing free verse,» he said, «is like playing tennis without a net.» He said you can only make free verse sound like poetry by intoning it as if you were in church. Frost was a very competitive man. He knew he was a great poet and he wanted to be compared with great poets. But he felt that the comparison would only be valid if he used the forms which they had used. Like the first 
Puritans, he did not see his task as the creation of something new, he saw it as bringing the best of the old to flourish in a new setting.

In a late, funny and brilliant poem, «How Hard It Is To Keep From Being King When It's In You And In The Situation,» Frost makes a great poetic joke that sums up his poetic creed. In the Bible in English, when Moses addresses the burning bush and asks its identity, God answers, «I am Who am.» Frost turns this into, «Iamb, Jehovah said, and he meant it.» But Ezra Pound said, «The first heave was to break the pentameter.» And William Carlos Williams said, "We must take the iambic pentameter line and wring its neck.» So it would seem simple. There are those who embraced free verse and those who did not. But life, friends, is never that simple. And neither is poetry.

So let's go back to London again and consider Ezra Pound. Why had he come to London? For the same reason Whistler had before him. These two barbarian aesthetes had come to conquer a capital with a new doctrine of art. And Pound soon met up with Tom Eliot who had come to London by accident. In Germany on a doctoral fellowship when war broke out in August, 1914, he had to leave and so came to London. He later tried to join the navy and when he was rejected -a hernia- he joined Pound instead and the two of them set out to make the world suitable for poetry.

Pound and Eliot. Eliot and Pound. Pound and Eliot, Inc. Eliot and Pound, S. A. Putting them together makes me very aware of their differences, but for now they are the Pound-Eliot Corporation. And what exactly were they marketing? A poetry very self-conscious of itself as poetry. Like Henry James before them, they felt that the soil of America was too thin and the climate too arid to sustain so complex a plant as literature. And they came, young and brash, like Jamesian characters, to claim their inheritance -all the best that had been written in Europe.

But if their own country was too crude, too capitalist and too uncouth for poetry, England was only a little better. For them, the problem with English poetry was that it was far too narrow, far too complacent, far too provincial, far too self-referent. In a word, far too British.

These American exiles called for a new cosmopolitanism in poetry. Their logic goes something like this: Americans are obviously destined to be the poets of the new era. But the poet of the new era will be characterized by his knowledge of past poetry and his use of that poetry. (Eliot's poetry is filled with allusions because he believes that poetry is made out of poetry.) So they sent their unlettered countrymen (and their British hosts) back to school. If you would be a poet, said Eliot, read Laforgue until you are fourteen and Dante thereafter. Pound prescribed the Provencal poets. They represent an extreme of one part of the American dilemma. Did America come into being to be completely new or to preserve, protect, defend and develop the best that Europe had to give?

The answer of Pound and Eliot is clear. The American poet must be a citizen of the polis of poetry. Whitman had said, «Walking freely out from the old traditions, as our politics has walked out, American poets recognize nothing behind them superior to what is present with them.» Eliot countered with the tradition with which any individual talent must come to terms! There are few more diametrically opposed statements in the long history of poetic theory and yet both of the contradictory positions are true and valid.

But that is part of my conclusion. I want to consider now what Eliot and Pound, Inc., owes to Whitman. Pound summed it up in «A Pact»: 
I make a pact with you, Walt Whitman.

I have detested you long enough.

I come to you as a grown child

Who has had a pig-headed father;

I am old enough now to make friends.

It was you that broke the new wood,

Now is a time for carving.

We have one sap and one root

Let there be commerce between us.

Whitman had broken the new wood. He had freed poetry from the constraints of pregiven form and the idea of consistent form within a poem. He had made it possible for Pound to say that we must have poetry of the musical phrase, not of the metronome.

But there was never to be an easy commerce between them. Within the brilliant rhymes of Prufrock you can feel the poetic energy straining at its metrical bonds. Indeed the careers of both Eliot and Pound are predicated upon the existence of free verse. The alliance, however, was uneasy. Whitman was simply not learned enough; an untutored genius, he didn't understand the crucial role of the traditional in the creation of the truly new. And, in fact, when Eliot and Pound first joined forces, they even denied free verse. Both thought that free verse had already become too loose, too flaccid, too free. «Poetry should be at least as well-written as prose,» they said, and from 1916 to 1921, they vied in the production of chiseled quatrains. True to their belief that poetry in English must be historical and international, Pound's quatrains contain rhyming puns in Greek and Eliot's include allusions to the Church Fathers and classical drama.

Then, in 1922, everything changed. Tom Eliot, suffering the agonies of a hideous marriage and consequent nervous breakdown, wrote, as he convalesced, the most famous poem of the twentieth century.

The Waste Land has become so famous, almost notorious, that an important element in its genesis has been overlooked. It owes a lot to. Pound-Eliot, Inc. And it's not simply the editing job that Pound did on the manuscript. The two poets were again vying, this time to describe the end of a world. Pound and Eliot had come, eager young men, to absorb all that Europe had to offer. With genuine American naivete, they saw EUROPE as a thing, a cultural entity, a vast reserve of aesthetic treasure which had endowed its boisterous offspring in a miserly fashion and which had to be confronted directly if it were to yield up its treasure. The horror of 1914-1918 stunned them. They realized that their «Europe» and its «tradition» existed only in their imaginations and from their shattered dreams came two great poems.

Pound's Hugh Selwyn Mauberly and Eliot's The Waste Land are companion poems, bookend poems - the responses of two American poets to the war which destroyed their illusions about the redeeming value of art, the civilizing power of culture. Pound writes of that war:

There died a myriad

And of the best among them

For an old bitch gone in the teeth

For a botched civilization.

For two gross of broken statues

For a few thousand battered books. 
Eliot, in his poem about the space between a man and a woman, takes his title and central metaphor from that devastated no man's land between the trenches. He too says that only pieces remain: "These fragments I have shored against my ruins.»

But Eliot's is the greater poem in part because he risks more. It is a very Whitmanesque risk. The poem is very personal and the elaborate paraphernalia of allusion and quotation enables the fastidious poet to confess the sordid shambles of his life. It turns out after all that the high priest of impersonal poetry was a confessional poet all along and was only playing possum with all that French and Sanskrit in the poetry.

And The Waste Land is an American poem. It was written by an American citizen who had spent twenty-five of his thirty-four years in his native land. I once heard a British woman say that The Waste Land is set in London and is therefore a British poem. By that logic, Moby Dick is a Polynesian novel. Only an American could have written The Waste Land. The magnificent heritage of five centuries of great poetry had had the effect of locking British poetry into moulds from which it could not escape. Only an American, another rebellious son of Whitman, could have, one, written in free verse; two, written in the discontinuous form pioneered by Whitman (who generously credited Poe with the idea); three, made his own sexual discontent the pivot of a poem about the end of western civilization.

But Eliot went on to become a classicist in literature, a royalist in politics, an Anglo-Catholic in religion and a loyal subject of King George V. He covered his American traces carefully.

One of the most interesting responses to The Waste Land came from William Carlos Williams. He hated it! And since he was an old and good friend of Pound -to whom the poem is dedicated- the correspondence is fascinating. Williams hated the poem because he thought it negated all that Whitman had been trying to do. The poem was too learned! German, French, Sanskrit and a cock that crows in Portuguese! It was elitist. It was reactionary! It was decadent and un-American too! And, worst of all, it was so damn good! It was so good, Williams said, it would set back American poetry for a hundred years while poets went chasing after grails and Tarot cards instead of looking at and writing about baseball games and weeds and the other «pure products of America.» Williams wanted poetry in the American grain and for Eliot to use his great talent to create a pastiche of past poems was an act of treason (later rivalled by the treason of his old friend $\mathrm{Ez}$ ).

That's why Williams said that there wasn't any such thing as American poetry. $\mathrm{He}$ said that when he was singlemindedly devoted to writing a Whitmanesque poetry of American people in American phrases with American words. But the world of poetry from the '20's through the '50's was dominated by imitations of Eliot; the learned, allusive, ironic poetry that Williams hated because it was so European.

Then, in 1956, a young poet who had lived near Williams in New Jersey brought him a book of poems which he had written. Williams wrote a preface for the book. Howl was published and the second Whitman revolution in American poetry began with:

I saw the best minds of my generation destroyed by madness, starving hysterical naked dragging themselves through the negro streets at dawn looking for an angry fix....

Howl and The Waste Land. Both monuments and models for American poetry, both sustaining sources in a divided tradition. 
I could go on to consider the career of Robert Lowell who, in his very productive poetic life, managed to embody all of the strains of American poetry I have mentioned -and some that I've left out. But I want now to come to some conclusions.

I hope I have not merely been conducting a literary survey. You know the kind: as the tour bus leaves Amherst you can see Emily Dickinson scribbling in the attic and there will be a rest stop before we watch Robert Frost mend a wall. I hope I have been describing a struggle, a dialectic, a discontinuity as poets struggle to create that much debated and much desired thing -an authentic American poetry. That struggle is still going on and I have tried to describe the parties or tribes to which poets give their allegiance -and, as often, change it.

But because the goal was common -a new poetry for a new world- and because the means were common -the English language as spoken by Americans- even the most antagonistic antagonists shared some features. So parts of Williams's projected epic, Paterson, are indistinguishable from some of the later poetry of Eliot. And Eliot, who never mentions Whitman in his poetry or voluminous prose, pays him the great tribute of imitation.

In the «American Quartet,» The Dry Salvages, Eliot, writing of his boyhood in St. Louis, beside the Mississippi River, begins:

I do not know much about gods; but I think that the river Is a strong brown god....

The good grey poet would have smiled at the compliment.

So I think there is such a thing as American poetry, and it is like the country that made it -fifty sovereign states in one. For me, this division is the power and the glory of American poetry. Long lines and short lines. Poetry with and without nets. Nativists and cosmopolites. Poetry of capacity and poetry of intensity. These are the contenders and, as in any long struggle, each side takes on some characteristics of the other. And this is all to the good. As Blake said, "Without contraries, there is no progression.» And as William Butler Yeats said, «Out of our quarrels with others we make rhetoric; out of our quarrels with ourself we make poetry.» I hope American poetry continues to quarrel with itself. 